\title{
SALINITY TOLERANCE OF LABORATORY REARED JUVENILES OF THE FAT SNOOK CENTROPOMUS PARALLELUS
}

\author{
Mônica Yumi Tsuzuki*, Vinícius R. Cerqueira, Andressa Teles \& Sara Doneda
}

\author{
Universidade Federal de Santa Catarina \\ Laboratório de Piscicultura Marinha, Departamento de Aqüicultura, Centro de Ciências Agrárias \\ (Caixa Postal 476, 88040-970, Florianópolis, SC, Brazil) \\ *Corresponding author: mtsuzuki@cca.ufsc.br
}

\begin{abstract}
A B S T R A C T
The knowledge of salinity tolerance is essential for aquaculture production in different water sources, as well as for stocking enhancement programs. In the present experiment, salinity tolerance was investigated in laboratory reared juveniles of the fat snook Centropomus parallelus. Fish of 52 days (22.0 $\mathrm{mm} \pm 0.4$ : mean total length $\pm \mathrm{SEM}), 59$ days $(22.6 \mathrm{~mm} \pm 0.5)$ and 73 days $(25.8 \mathrm{~mm} \pm 0.5)$ after hatching (DAH) were directly transferred from 35 to $0,5,15$ and 35 ppt. Survival was checked every $24 \mathrm{~h}$ during a $96-\mathrm{h}$ period. The experiment was carried out with fed (for all salinities) and unfed individuals (except for $5 \mathrm{ppt}$ ). Direct transfer resulted in less than $40 \%$ mortality in all treatments and ages tested. At the same salinity level, no difference in survival rates was found between fed and unfed juveniles, at the different ages and exposure time tested. Juveniles of 52 DAH presented lower tolerance to $0 \mathrm{ppt}$ compared to other salinities. In older juveniles (59 and $73 \mathrm{DAH}$ ), mortality after 96 $\mathrm{h}$ was very low ( $\geq 95 \%$ survival), regardless the salinity treatment or feeding condition. Therefore, the present study showed that juveniles of $52 \mathrm{DAH}$ are less tolerant to abrupt transfer to freshwater, indicating that a salinity acclimation procedure prior to release in freshwater areas would be necessary, and that tolerance increased with increasing age.
\end{abstract}

\section{R E S U M O}

O conhecimento da tolerância à salinidade é essencial para produção em aquacultura em diferentes ambientes aquáticos, bem como para programas de repovoamento. No presente experimento, a tolerância à salinidade foi investigada em juvenis de robalo-peva Centropomus parallelus. Peixes de 52 dias $(22,0 \mathrm{~mm} \pm 0,4$ : média comprimento total $\pm \mathrm{EP}), 59$ dias $(22,6 \mathrm{~mm} \pm 0,5)$ e 73 dias $(25,8 \mathrm{~mm}$ $\pm 0,5$ ) após eclosão (DAE) foram diretamente transferidos de 35 para $0,5,15$ e 35 ppt. Sobrevivência foi monitorada a cada $24 \mathrm{~h}$ durante um período de $96 \mathrm{~h}$. O experimento foi conduzido com animais alimentados (todas as salinidades) e em inanição (exceto para 5 ppt). Transferência direta resultou em menos de $40 \%$ de mortalidade em todos os tratamentos e idades testadas. No mesmo nível salino, não foram encontradas diferenças nas taxas de sobrevivência entre juvenis alimentados e em inanição nas diferentes idades e tempos de exposição testadas. Juvenis de 52 DAE apresentaram menor tolerância a 0 ppt em comparação as demais salinidades. Em animais mais velhos (59 e 73 DAE), mortalidade após $96 \mathrm{~h}$ foi muito baixa ( $\geq 95 \%$ sobrevivência), independentemente do tratamento salino ou condição de alimentação. Portanto, o presente estudo mostrou que juvenis de 52 DAE são menos tolerantes a transferências abruptas à água doce, indicando que procedimento de aclimatação à salinidade antes da liberação em áreas dulcícolas é necessário, e que a tolerância aumenta com o aumento da idade.

Descriptors: Salinity tolerance, Fat snook, Centropomus parallelus, Juveniles.

Descritores: Tolerância à salinidade, Robalo-peva, Centropomus parallelus, Juvenis.

\section{INTRODUCTION}

The fat snook Centropomus parallelus is a commercial valuable fish species with wide distribution along the Brazilian coast, being captured by artisanal and sportive fisheries. It is considered as an euryhaline fish as it is naturally found in marine, brackish and freshwater environments (Chávez, 1963).

Some species of the Centropomus genus present potential for aquaculture, as they adapt well to captivity and accept artificial diets, are resistant to husbandry procedures and variations in water quality, and have a high market price due to the quality of their flesh (Chapman et al., 1982; Tucker Jr., 1987; Cerqueira, 2002). Previous works have dealt with some aspects of reproduction and larviculture of fat snook (Alvarez-Lajonchère et al., 2002a, b; Ferraz et al., 2002; Cerqueira, 2004, Temple et al., 2004; Cerqueira, 2005), and nowadays a massive production of juveniles is obtained under laboratory conditions (Alvarez-Lajonchère et al., 2002b). Nevertheless, growout studies are still necessary in order to determine the viability of its production at a 
commercial level. In this context, there is an increasing interest in growing fat snook in floating cages and earthern ponds in Brazil, using high quality water bodies available in coastal, estuarine and freshwater areas. Stocking enhancement programs that are also being established will release newly weaned laboratory reared fat snook in different bays of the country, where enviromental paramenters, especially water salinity can fluctuate significantly.

It is well known that salinity is one of the most significant environmental parameters influencing survival, growth and distribution of fish (Holliday, 1969; Beamish, 1970; Boeuf \& Payan, 2001). Water salinity can affect survival by diminishing fish feeding (Dendrinos \& Thorpe, 1985; Fielder \& Bardsley, 1999), and by modifying the energetic cost for osmotic and ionic regulation (De Boeck et al., 2000; Boeuf \& Payan, 2001).

So far, many aspects about the influence of salinity on young fat snook are uncertain. Therefore, the aim of this work is to determine the salinity tolerance limits of fat snook juveniles as an initial step in order to determine the viabilility and potential of fat snook cultivation at different salinities, as well as to select the best sites for natural stock enhancement.

\section{Materials And Methods}

Animals and General Rearing Conditions

The experiment was held at the Laboratório de Piscicultura Marinha (LAPMAR), Universidade Federal de Santa Catarina, Florianópolis, SC, Brazil, $27^{\circ} 37^{\prime} \mathrm{S}$ and $048^{\circ} 27^{\prime} \mathrm{W}$.

Larvae of the fat snook Centropomus parallelus, obtained by natural spawn of hormonally induced broodstock (Ferraz et al., 2002), were reared following methods described by Alvarez-Lajonchère et al. (2002b). Juveniles were weaned to an artificial $\operatorname{diet}(49.1 \%$ protein, $20.9 \%$ fat) approximately 45 days after hatching. Until the start of the experiments, they were kept at $25^{\circ} \mathrm{C}, 35 \mathrm{ppt}$ salinity, under natural photoperiod, fed a commercial dry pellet $(50.0 \%$ protein; $7.0 \%$ fat).

In all tests, salinity levels were obtained by mixing dechlorinated tap water with natural seawater. Salinity was measured with a Bernauer Model F3000 optical refractometer (1.0 ppt precision (Bernauer Aquacultura, Blumenau, Brazil).

\section{Salinity Tolerance Tests}

Juveniles of the fat snook of 52 days $(0.10 \mathrm{~g}$ $\pm 0.0 ; 22.0 \mathrm{~mm} \pm 0.4$ : mean wet weight and total length $\pm \mathrm{SEM}), 59$ days $(0.13 \mathrm{~g} \pm 0.0 ; 22.6 \mathrm{~mm} \pm 0.5)$ and 73 days after hatching (DAH) $(0.18 \mathrm{~g} \pm 0.0 ; 25.8$ $\mathrm{mm} \pm 0.5)$ were directly transferred from 35 to $0,5,15$ and $35 \mathrm{ppt}$ salinity, and kept for $96 \mathrm{~h}$. Treatments were performed with fed (at all salinities) and unfed animals (except at $5 \mathrm{ppt})$. Fish were fed dry pellets $(\geq 0.02 \mathrm{~g}$ per experimental unit). All treatments were run in triplicate.

Stocking densities were 20 juveniles (52 and $59 \mathrm{DAH}$ ), and 15 juveniles (73 DAH) per $2.5 \mathrm{~L}$ glasscontainers. Water temperature was kept at $25.3 \pm$ $0.1^{\circ} \mathrm{C}$.

Dissolved oxygen was $6.73 \pm 0.1 \mathrm{mg} \mathrm{l}^{-1}(0$ ppt); $6.50 \pm 0.1(5 \mathrm{ppt}) ; 6.04 \pm 0.1(15 \mathrm{ppt}) ; 5.39 \pm 0.1$ (35 ppt), measured with a YSI Model 51 oxygen meter (Yellow Springs Instrument Company, Yellow Springs, Ohio, USA). Total ammonia $\left(\mathrm{NH}_{3} / \mathrm{NH}_{4}{ }^{+}\right)$was measured with a Tetratest ${ }^{\circledR}$ Kit (Tetra Werke, Melle, Germany) and ranged from 0 to $0.25 \mathrm{mg} \mathrm{l}^{-1}$.

Every $24 \mathrm{~h}$, live and dead fish were counted, and $80 \%$ of the water was exchanged. Fish were considered dead when respiratory movement of the opercula stopped and there was no response to touch.

\section{Statistical Analysis}

As mortality rates did not reach $50 \%$ after a 96-h exposure, salinity tolerance limits, defined as the lethal time for $50 \%$ mortality $\left(\mathrm{LT}_{50}\right)$ and median lethal salinity (LS 50 ), could not be calculated by Probit Analysis as initially planned. Therefore, survival rates (after arcsine transformation) were compared by ANOVA, followed by Tukey test $(\mathrm{P}<0.05)$.

\section{Results and Discussion}

The fat snook Centropomus parallelus can be found in coastal areas, bays, estuaries and brackish lagoons, freshwater environments and occasionally in hypersaline lagoons (Cervigón et al., 1992), however, its natural distribution during the ontogenetic development has not been characterized. It is known that many juvenile fish species are found in intermediary to lower salinities of estuaries and coastal lagoons where they find advantageous conditions for growth. Nevertheless, the ability of each developmental stage to cope with salinity depends on their capacity of osmoregulation, a function resulting in given levels of salinity tolerance and ultimately, enabling them to occupy various habitats (Varsamos et al., 2006). Therefore, the present work focused on the evaluation of the salinity tolerance of fat snook at the juvenile phase at intermediate to lower salinities, as an initial step to determine the viabilility and potential of fat snook cultivation at these conditions, as well as to select the best sites for natural stock enhancement. 
Direct transfer from 35 to $0,5,15$ and $35 \mathrm{ppt}$ resulted in less than $40 \%$ mortality in all treatments, in fed and unfed animals of different ages. As the highest mortality rates occurred during the first $24 \mathrm{~h}$ after salinity change, data was presented as survival rates at $24 \mathrm{~h}$ (Table 1) and $96 \mathrm{~h}$ (Table 2). Survival rates at the end of the 96-h period were considered as the final response of the fish.

After $24 \mathrm{~h}$, fed juveniles of $52 \mathrm{DAH}$ had lower survival rates at $0 \mathrm{ppt}(83.1 \%)$ than juveniles at 5 ppt $(100 \%$ survival $) \quad(\mathrm{P}<0.05)$. No statistical difference was observed among treatments after $96 \mathrm{~h}$. Unfed juveniles, after 24 and $96 \mathrm{~h}$ had lower survival rates at $0 \mathrm{ppt}$ (around 60\%) than juveniles at 15 and 35 ppt $(>87 \%)$. In older juveniles (59 and $73 \mathrm{DAH})$, mortality rates after $96 \mathrm{~h}$ were very low $(\geq 95 \%$ survival) regardless the salinity treatment, in fed and unfed animals.

Therefore, the present study showed that 52 $\mathrm{DAH}$ juveniles are less tolerant to abrupt transfer to freshwater, especially in unfed animals, indicating that a salinity acclimation procedure prior to release in freshwater areas would be necessary. However, tolerance to $0 \mathrm{ppt}$ increased with increasing age (59 and $73 \mathrm{DAH})$. Hence, the best age for releasing newly weaned fat snook in stocking enhancement programs is from 59 DAH onwards, as almost $100 \%$ survival was obtained after direct transfer to fresh water. Increase in salinity tolerance with the ontogenetic development has been also reported for other marine fish (Holliday \& Jones, 1967; Lein et al., 1997; Zydlewski \& McCormick, 1997; Estudillo et al., 2000). A gradual change in tolerance to extreme salinities has been reported throughout the larval development, with transition to the juvenile phase often marking the time of occurrence of the salinity tolerance level of adults (Holliday \& Blaxter, 1960; Holliday, 1969).

Although fat snook juveniles showed high tolerance to abrupt salinity changes, Tsuzuki et al.

Table 1. Survival rates (\%) of fed and unfed fat snook juveniles of different ages, $24 \mathrm{~h}$ after direct transfer from 35 to $0,5,15$ and 35 ppt salinity. Values are means \pm SEM of three replicates. Means in the same column followed by different letters are significantly different $(\mathrm{P}<0.05)$.

\begin{tabular}{ccccccc}
\hline \hline & \multicolumn{2}{c}{$52 \mathrm{DAH}^{1}$} & \multicolumn{2}{c}{$59 \mathrm{DAH}$} & \multicolumn{2}{c}{$73 \mathrm{DAH}$} \\
\cline { 2 - 6 } $\begin{array}{c}\text { Salinity } \\
\text { (ppt) }\end{array}$ & fed & unfed & fed & unfed & fed & unfed \\
\hline 0 & & & & & & \\
\hline 5 & $83.1 \pm 7.2 \mathrm{a}$ & $65.0 \pm 5.0 \mathrm{a}$ & $98.3 \pm 1.7$ & $100.0 \pm 0.0$ & $97.8 \pm 2.2$ & $100.0 \pm 0.0$ \\
15 & $98.3 \pm 1.7 \mathrm{ab}$ & $98.3 \pm 1.7 \mathrm{~b}$ & $100.0 \pm 0.0$ & $100.0 \pm 0.0$ & $100.0 \pm 0.0$ & $100.0 \pm 0.0$ \\
35 & $98.3 \pm 1.7 \mathrm{ab}$ & $95.0 \pm 2.9 \mathrm{~b}$ & $100.0 \pm 0.0$ & $100.0 \pm 0.0$ & $100.0 \pm 0.0$ & $100.0 \pm 0.0$ \\
\hline
\end{tabular}

${ }^{1}$ Days After Hatching

Table 2. Survival rates (\%) of fed and unfed fat snook juveniles of different ages, $96 \mathrm{~h}$ after direct transfer from 35 to $0,5,15$ and $35 \mathrm{ppt}$ salinity. Values are means \pm SEM of three replicates. Means in the same column followed by different letters are significantly different $(\mathrm{P}<0.05)$.

\begin{tabular}{ccccccc}
\hline \hline & \multicolumn{2}{c}{$52 \mathrm{DAH}^{1}$} & \multicolumn{2}{c}{$59 \mathrm{DAH}$} & \multicolumn{2}{c}{$73 \mathrm{DAH}$} \\
\cline { 2 - 6 } $\begin{array}{c}\text { Salinity } \\
(\mathrm{ppt})\end{array}$ & fed & unfed & fed & unfed & fed & unfed \\
\hline 0 & & & & & & \\
\hline 5 & $83.1 \pm 7.2$ & $60.0 \pm 7.6 \mathrm{a}$ & $94.8 \pm 3.0$ & $98.4 \pm 1.7$ & $97.8 \pm 2.2$ & $95.6 \pm 2.2$ \\
15 & $100.0 \pm 0.0$ & - & $100.0 \pm 0.0$ & - & $100.0 \pm 0.0$ & - \\
35 & $93.4 \pm 4.4$ & $93.4 \pm 4.4 \mathrm{~b}$ & $98.4 \pm 1.7$ & $98.4 \pm 1.7$ & $97.8 \pm 2.2$ & $100.0 \pm 0.0$ \\
\hline
\end{tabular}

${ }^{1}$ Days After Hatching 
(2006) obtained best results for food conversion ration (FCR) and activity of digestive enzymes at $15 \mathrm{ppt}$ in animals of 76 DAH. At this salinity level, animals presented higher potential for a more efficient digestibility and nutrient absorption for the energetic metabolism. This could be directed to fish growth, as at this salinity probably the metabolic demand is reduced by the isosmotic medium.

Usually, fish are not fed in 24-96 h salinity tolerance tests (Anyanwu, 1991; Hotos \& Vlahos, 1998; Estudillo et al., 2000). Duenas \& Young (1983) and Estudillo et al. (2000) used $48 \mathrm{~h}$ as the maximum time to test for tolerance without non-salinity related complications such as starvation and poor water quality in milkfish Chanos chanos and mangrove red snapper Lutjanus argentimaculatus, respectively. However, due to the aggressive and cannibal behaviour of fat snook, and a long salinity exposure time $(96 \mathrm{~h})$, the present experiment was performed with fed and unfed fish. Cannibalism is frequently cited as the major mortality cause among juveniles of this species, mostly observed after 30 days after hatching (Alvarez-Lajonchère et al., 2002b). Surprisingly, no statistical differences between survival rates was verified in fed and unfed fat snook juveniles at the same salinity level, age and exposure time. Therefore, cannibalism did not affect mortality rates in the present experiment.

Fielder \& Bardsley (1999) observed that juveniles of mulloway Argysomus japonicus, an estuarine scianidae, were able to survive in fresh water for two days, but did not feed. After three days, some fish died, while others lost equilibrium and swan upside down. From the results obtained here, we can conclude that laboratory reared juveniles of fat snook can cope well with an abrupt decrease in salinity (below $35 \mathrm{ppt}$ ), at least for $96 \mathrm{~h}$, even without being fed. This fact is important, particularly when animals are submitted to a food restriction or a starvation period due to food inadequacy, food shortage, or when fish refuse to eat as a stress or disease response. This could be the case when they are released in fluctuating salinities or in different saline waters for growout.

\section{ACKNOWLEDGEMENTS}

This work was supported by the Conselho Nacional de Desenvolvimento Científico e Tecnológico $(\mathrm{CNPq})$ through research grants and scholarships. We would like to thank Israel Diniz, Jaqueline Araújo and Antônio Carlos Sayão as well as the rest of the group at LAPMAR for their technical assistance.

\section{REFERENCES}

Alvarez-Lajonchère, L. S.; Cerqueira, V. R. \& Reis, M. A. 2002a. Desarrollo embrionario y primeros estadios larvales del robalo gordo, Centropomus parallelus Poey (Pisces, Centropomidae) con interés para su cultivo. Hidrobiológica, 12:89-99.

Alvarez-Lajonchère, L. S.; Cerqueira, V. R.; Silva, I. D.; Araújo, J. \& Reis, M. A. 2002b. Mass production of juveniles of the fat snook Centropomus parallelus in Brazil. J. World Aquac. Soc., 33:506-516.

Anyanwu, P. E. 1991. Influence of salinity on survival of fingerlings of the estuarine catfish Chrysichthys nigrodigitatus (Lacépède). Aquaculture, 99:157-165.

Beamish, F. W. H. 1970. Influence of temperature and salinity acclimation on temperature preferenda of the euryhaline fish Tilapia nilotica. J. Fish. Res. Board Can., 27:1209-1214.

Boeuf, G. \& Payan, P. 2001. How should salinity influence fish growth? Comp. Biochem. Physiol., Part C, 130:411423.

Cerqueira, V. R. 2002. Cultivo do Robalo: Aspectos da Reprodução, Larvicultura e Engorda. Universidade Federal de Santa Catarina - Ed. do Autor, Florianópolis, Brasil.

Cerqueira, V. R. 2004. Cultivo de peixes marinhos. In: Poli, C.R.; Poli, A.T.B; Andreatta, E.R. \& Beltrame, E., eds. Aqüicultura: Experiências Brasileiras. Florianópolis, SC:, Multitarefa. p.369-406.

Cerqueira, V. R. 2005. Cultivo do robalo-peva (Centropomus parallelus). In: Baldisserotto, B. \& Carvalho Gomes, L., eds. Espécies nativas para piscicultura no Brasil. Santa Maria, RS, Editora da Universidade Federal de Santa Maria. p.403-431.

Cervigón, F.; Cipriani, R.; Fischer, W.; Garibaldi, L.; Hendrick, M.; Lemus, A. J.; Márquez, R.; Poutiers, J. M.; Robaina, G. \& Rodriguez, B. 1992. Fichas FAO de identificación de especies para los fines de la pesca. Guía de campo de las especies comerciales marinas y de aguas salobres de la costa septentrional de Sur América. Rome: FAO.

Chapman, P.; Cross, F.; Fish, W. \& Jones, W. 1982. Final report for sportfish introductions project. Study I: Artificial culture of snook. Florida: Florida Game and Freshwater Fish Commission, USA.

Chávez, H. R. 1963. Contribución al conocimiento de los robalos, chucumite y constantino (Centropomus spp) del Estado de Veracruz, Mexico. Ciencia, 22:141-161.

De Boeck, G.; Vlaeminck, A.; Van der Linden, A. \& Blust, R. 2000. The energy metabolism of common carp (Cyprinus carpio) when exposed to salt stress: an increase in energy expenditure or effects of starvation? Physiol. Biochem. Zool., 73:102-111.

Dendrinos, P. \& Thorpe, J. P. 1985. Effects of reduced salinity on growth and body composition in the european bass Dicentrarchus labrax (L). Aquaculture, 49:333358.

Duenas, C. E. \& Young, P. S. 1983. Salinity tolerance and resistance of milkfish larvae. In: International Milkfish Aquaculture Conference, 2. Book of Abstracts. Illoilo, Phillippines, 4-8 October 1983. p. 22. 
Estudillo, C. B.; Duray, M. N.; Marasigan, E. T. \& Emata, A. C. 2000. Salinity tolerance of larvae of the mangrove red snapper Lutjanus argentimaculatus during ontogeny. Aquaculture, 190:155-167.

Ferraz, E. de M.; Cerqueira, V. R. \& Alvarez-Lajonchère, L. S. 2002. Indução da desova do robalo-peva, Centropomus parallelus, através de injeção e implante de LHRHa. Bol. Inst. Pesca, 28:125-133.

Fielder, D. S. \& Bardsley, W. 1999. A preliminary study on the effects of salinity on growth and survival of mulloway Argyrosomus japonicus larvae and juveniles. J. World Aquac. Soc., 30:380-387.

Holliday, F. G. T. 1969. The effects of salinity on the eggs and larvae of teleosts. In: Hoar, W.S. \& Randall, J.D. eds. Fish Physiology, vol.1. New York: Academic Press. p. 293-311.

Holliday, F. G. T. \& Blaxter, J. H. S. 1960. The effects of salinity on the developing eggs and larvae of the herring. J. Mar.Biol.. Ass. U.K., 39:59- 603.

Holliday, F. G. T. \& Jones, M. P. 1967. Some effects of salinity on the developing eggs and larvae of the plaice (Pleuronectes platessa). J. Mar.Biol. Ass. U.K., 47:3948.

Hotos, G. N. \& Vlahos, N. 1998. Salinity tolarance of Mugil cephalus and Chelon labrosus fry in experimental conditions. Aquaculture, 167:329-338.

Lein, I.; Tveite, S.; Gjerde, B. \& Holmefjord, I. 1997. Effect of salinity on yolk sac larvae of Atlantic halibut (Hippoglossus hippoglossus L.). Aquaculture, 156:291303 .
Temple, S.; Cerqueira, V. R. \& Brown, J. A. 2004. The effects of lowering prey density on the growth, survival and foraging behaviour of larval fat snook (Centropomus parallelus Poey, 1860). Aquaculture, 233:205-217.

Tsuzuki, M. Y.; Sugai, J. K.; Maciel, J. C.; Francisco, C. J. \& Cerqueira, V. R. 2006. Effect of salinity on survival and growth of the juveniles of the fat snook Centropomus parallelus. . In: Latin American Aquaculture of Native Fishes Conference, 1., Morélia, México, 18-20 October 2006. Book of Abstracts. p. 43.

Tucker Jr., J. W. 1987. Snook and tarpon snook culture and preliminary evaluation for commercial farming. Prog. Fish-Cult., 49:49-57.

Varsamos, S.; Nebel, C. \& Charmantier, G. 2005. Ontogeny of osmoregulation in postembryonic fish: A review. Comp. Biochem. Physiol. A Mol. Integr. Physiol., 141(4):401-429.

Zydlewski, J. \& McCormick, S. D. 1997. The ontogeny of salinity tolerance in the American shad, Alosa sapidissima. Can. J. Fish. Aquat. Sci., 54:182-189.

(Manuscript received 17 May 2006; revised 23 October 2006; accepted 06 November 2006) 